
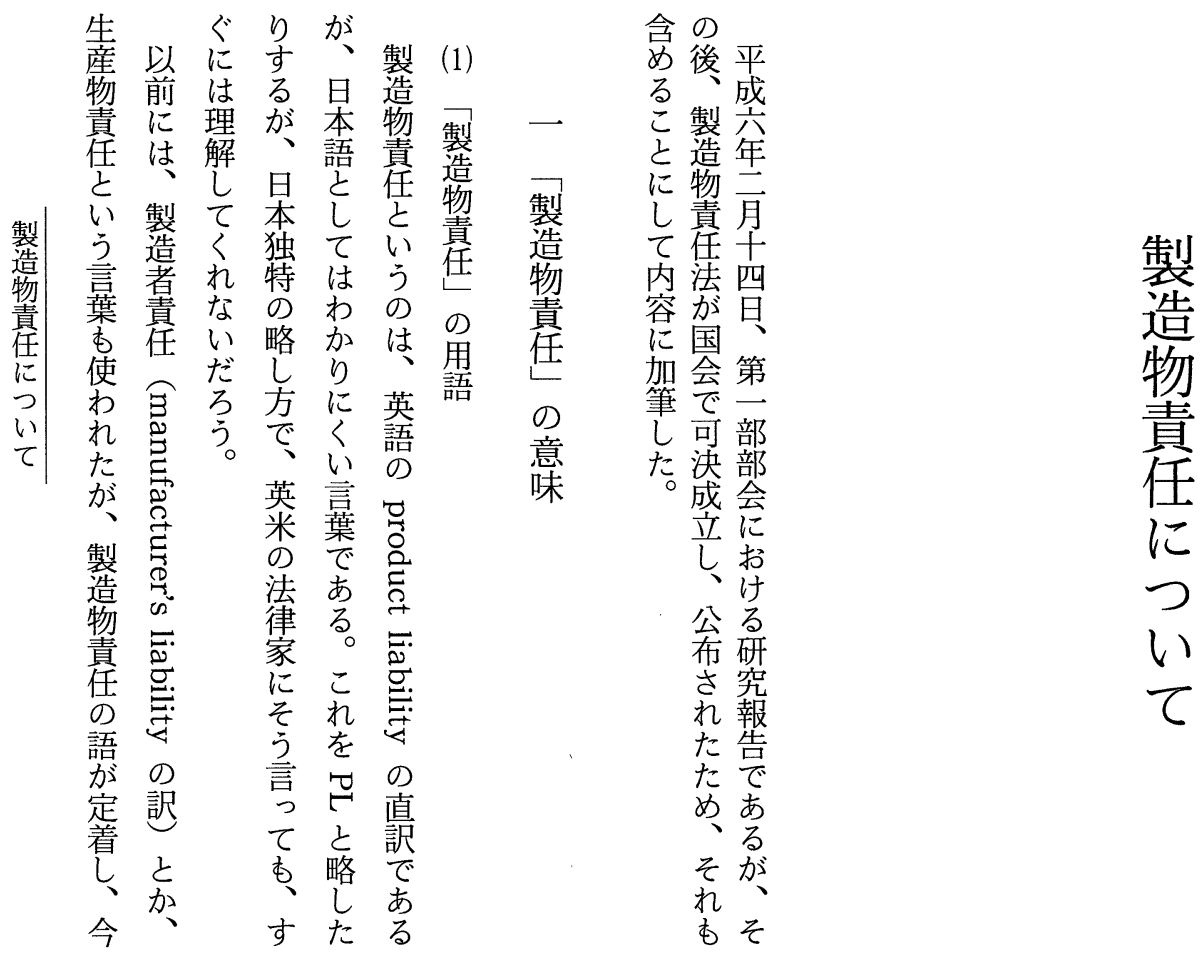

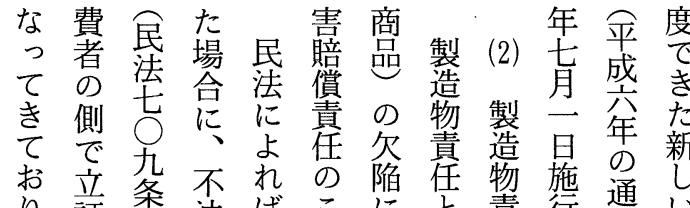

り証条法ばこに占責行常い

まな製為製でっうの 会律

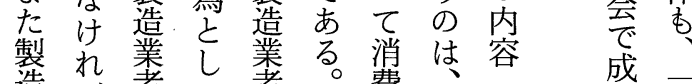

造ば者て者。費

過な過損は、著製

号告害そ兴業

資い然贘過侣者

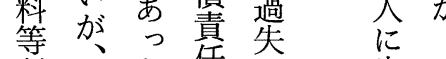

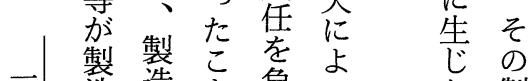

茂製

物

年 䩀

旨 洼

$\begin{array}{cc} & \text { 平 } \\ & \text { 嵗 } \\ & \text { 年 } \\ \text { 会 } & \text { 㝵 } \\ \text { 員 } & \text { 罟 } \\ & \text { 加 } \\ & \text { 提 } \\ & \text { 出 }\end{array}$

藤

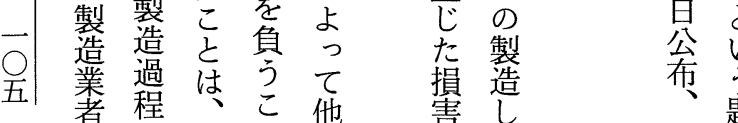

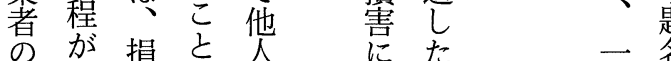

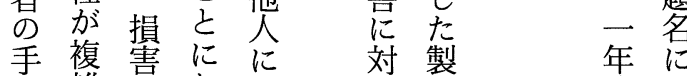

中雑吉な損造後な

に・受っ害年物方っ

あ高けて袁負物 平

状に消る 


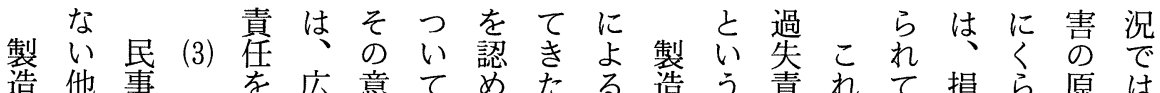

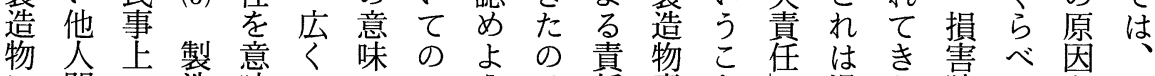

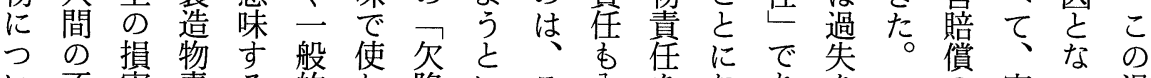
い不害責る的わ陮いこ入艺なあを客っ過 て法賠任、なれ責うのるる方り要責観た失 見行償のと製て任こ過こ製。莝件任的製

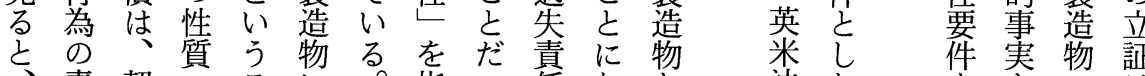

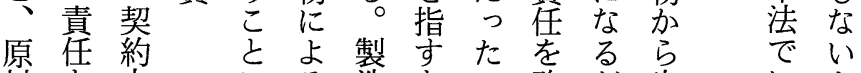

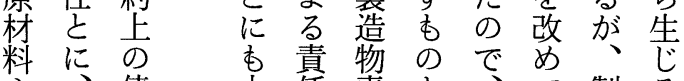

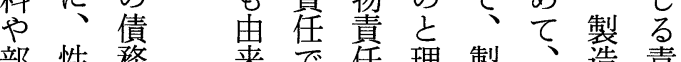

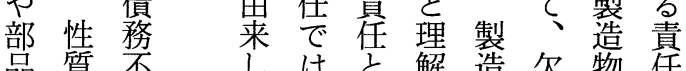

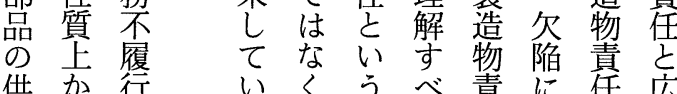

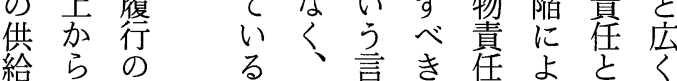

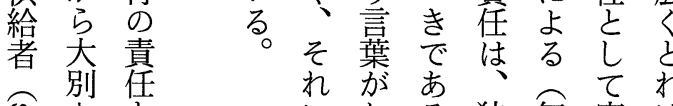

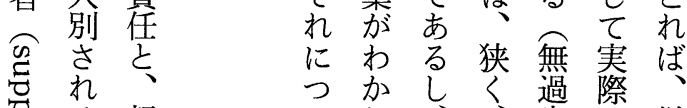

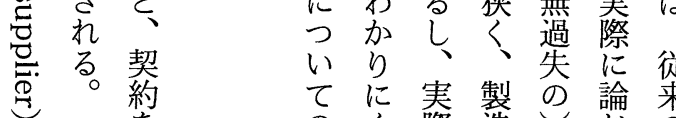

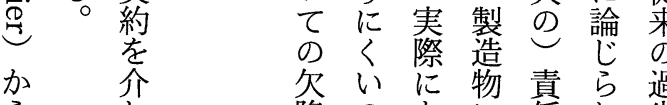
吕介尔い少物責ら過 でいなとし決

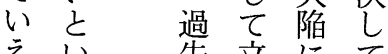
えい失音にて 第 ばう加証つ容草

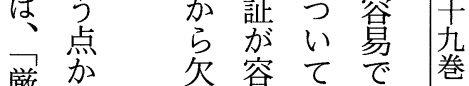

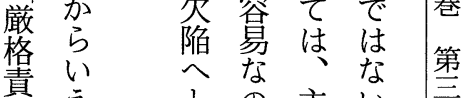

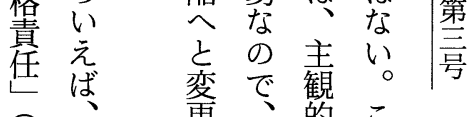

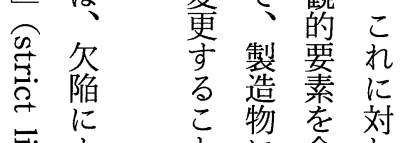

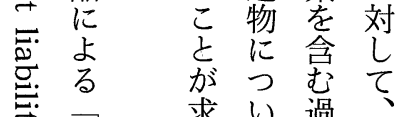
々係る。簡為れで関典 李こ堡物こ主第費が製 うがなでし可くのでるの任㩔のに章へ(2)造

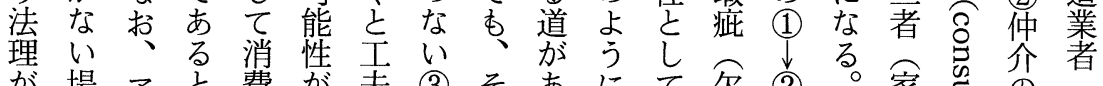

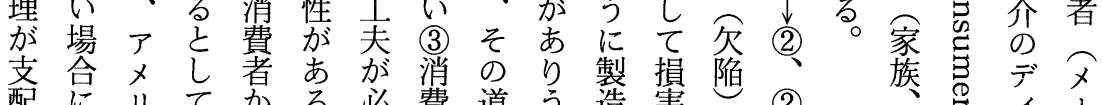

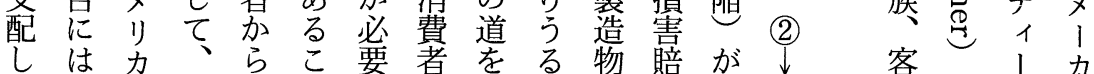

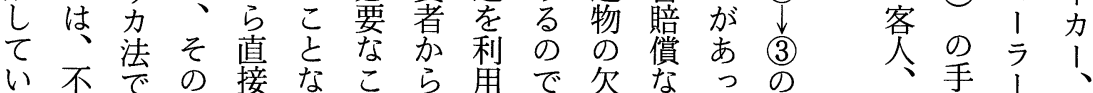

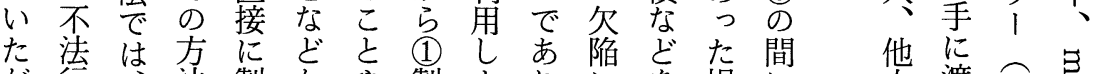

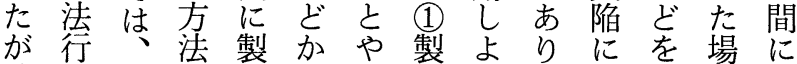

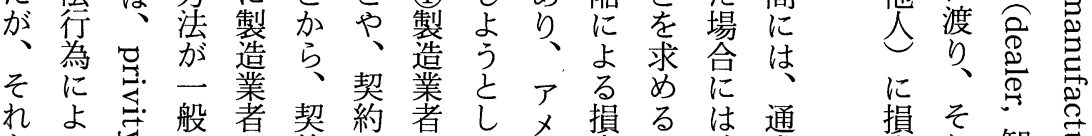

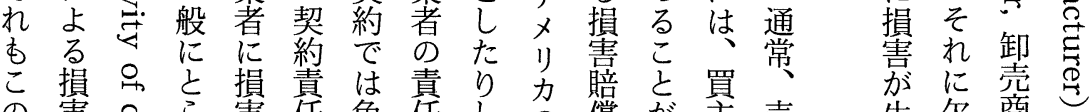

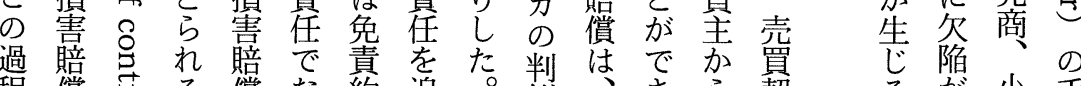

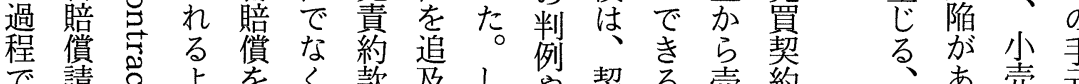

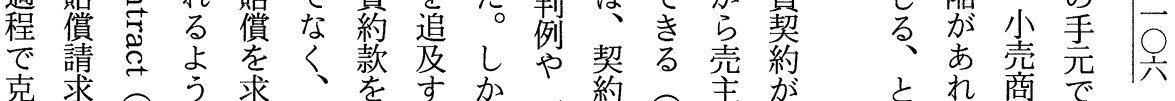
さ認約なる人狆の、气任法対り う筶 れめのっの間てに直在と五し、過消経ざ

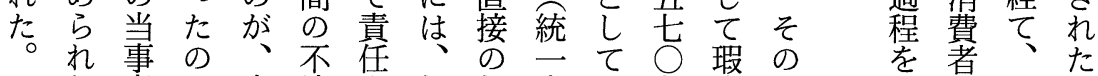

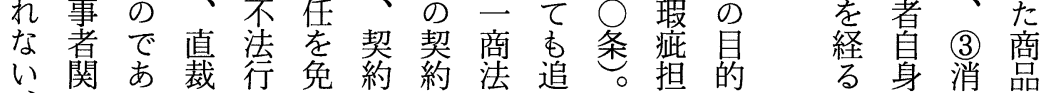




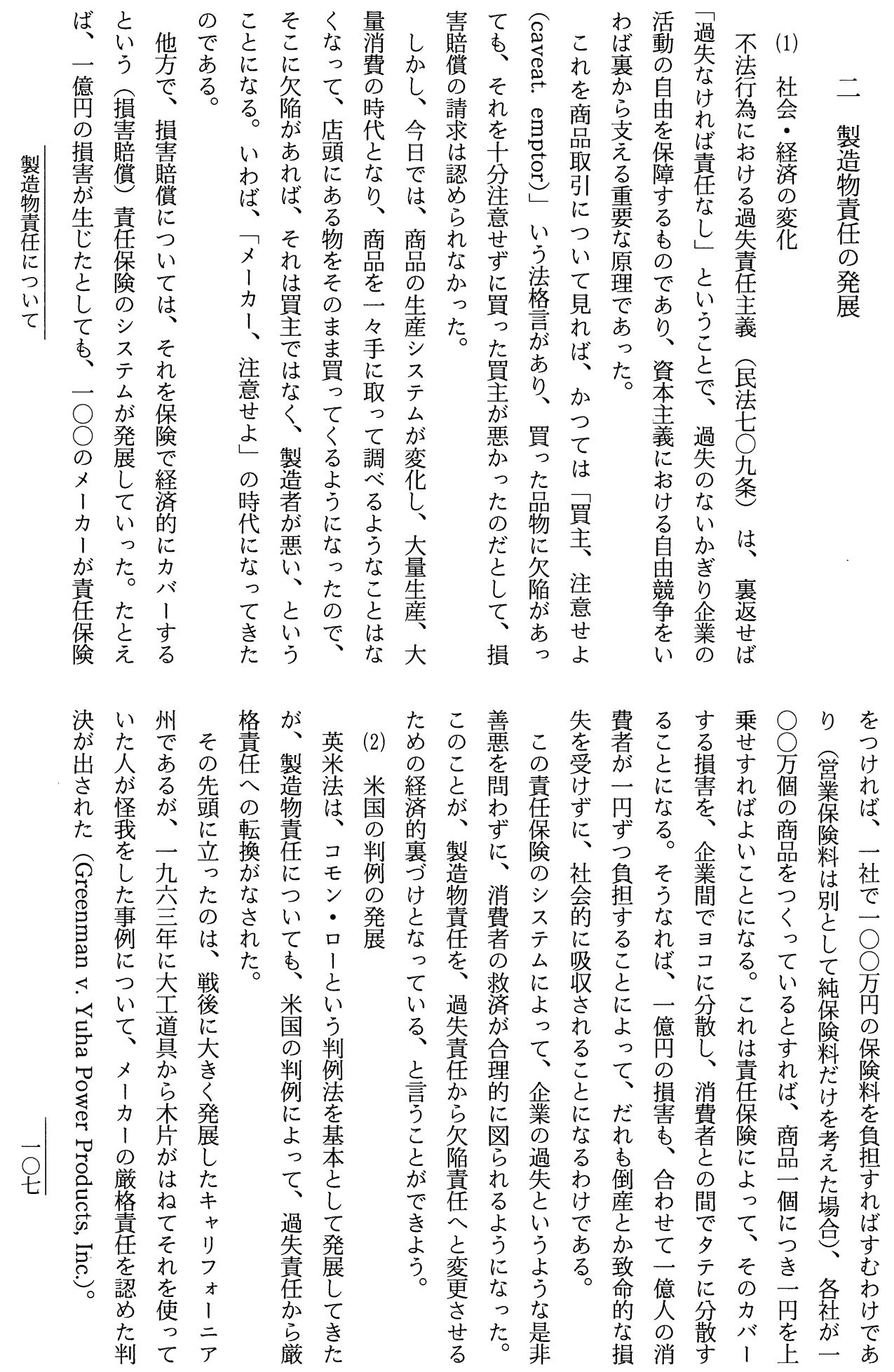




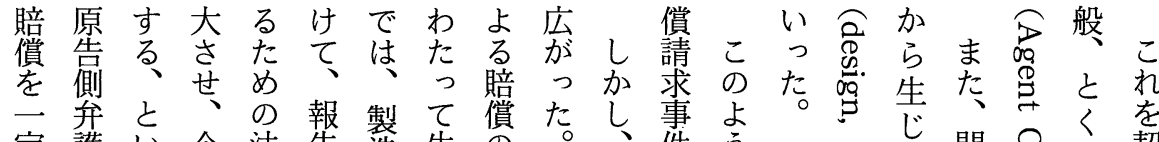

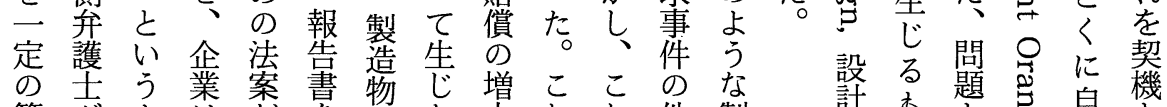

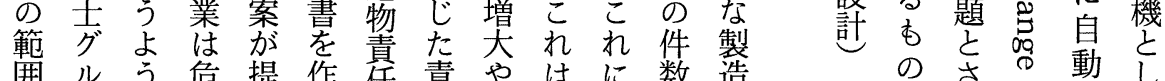

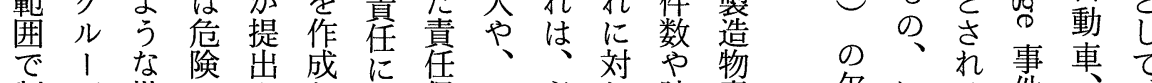

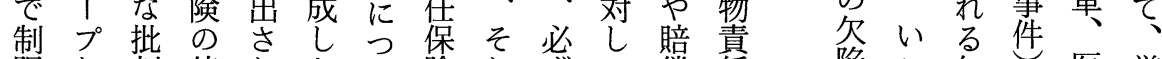
限な判伴れたい険れずて僓在樎わ尔医厳 すどがうたりてのにしは額の、ば陥や薬格

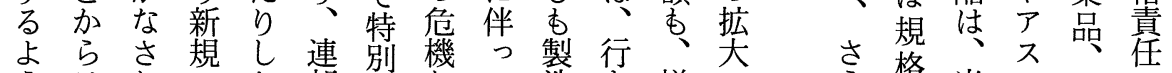

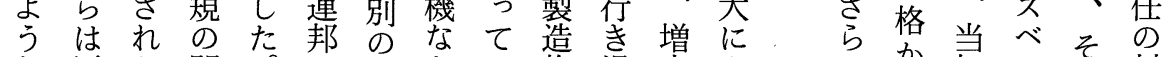

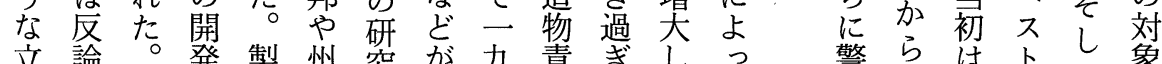

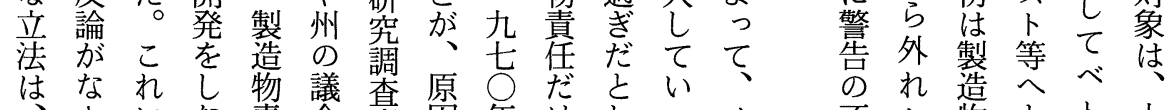

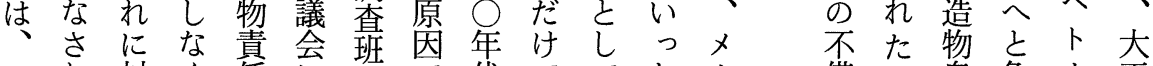

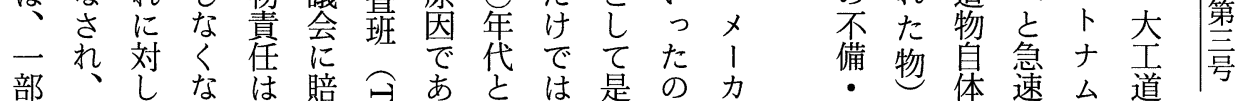

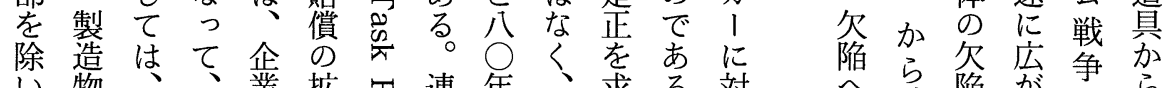

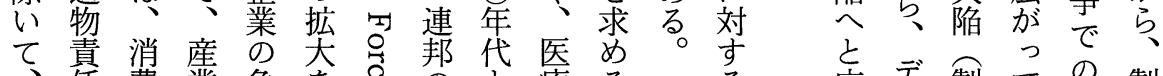

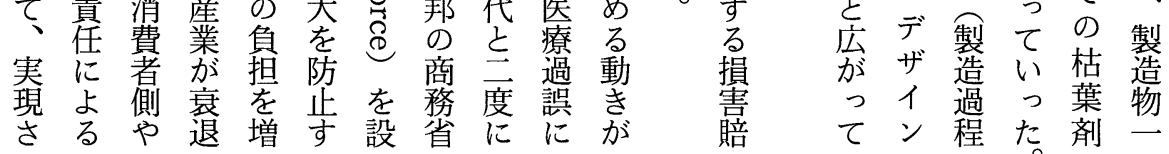

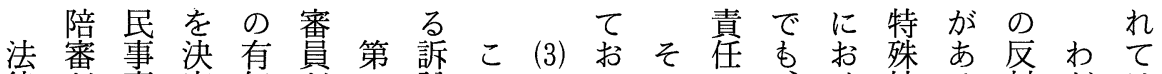

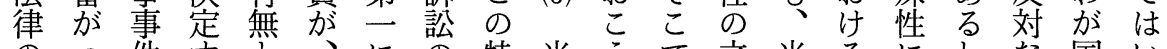

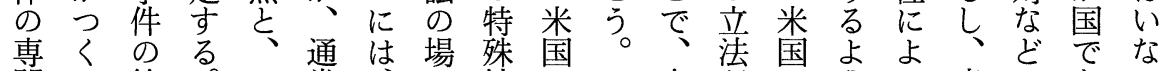

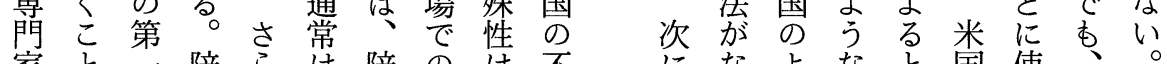

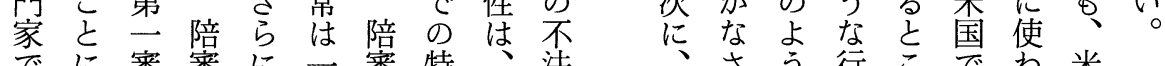
でに審番に三番特不法、さう行こでわ米 あなでは責二制殊不行米れにきろのれ国 るっはす任公度性法為国たな過が賠たで 裁て、とがで肪だ行損市のっぎ大償りの 判い両はあ構あと為害不ちてがき留

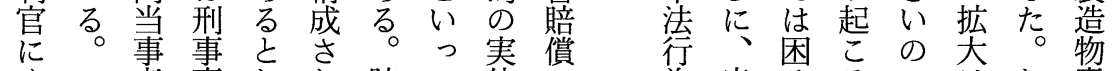

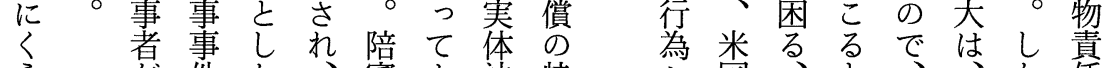

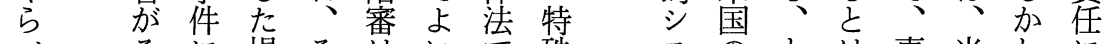
べそ場そはいで殊 スのとは事米しに

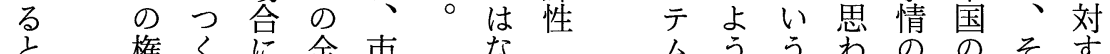

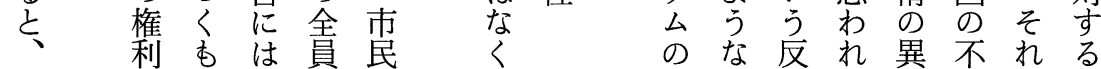

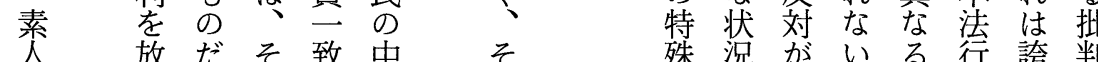

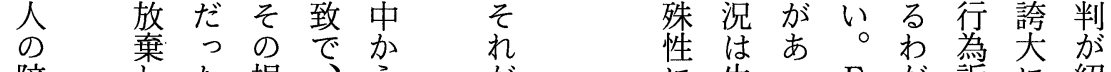

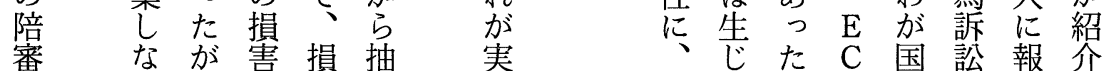

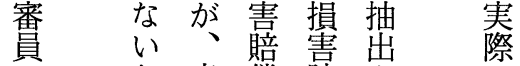

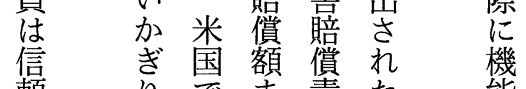

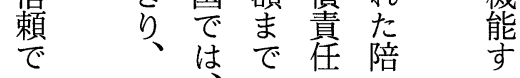

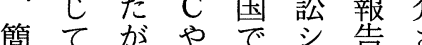

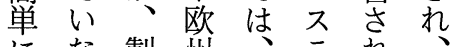
にな製州、テれ

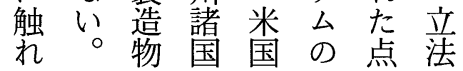




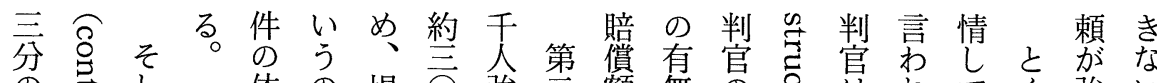

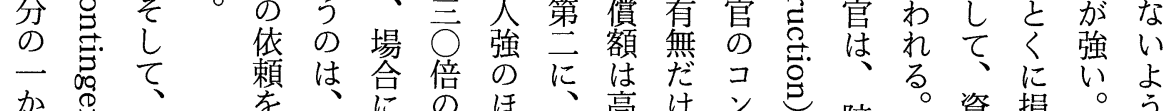

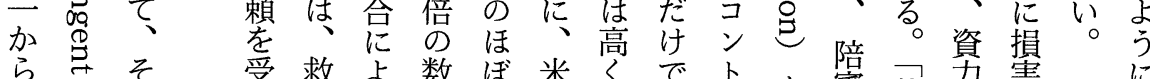

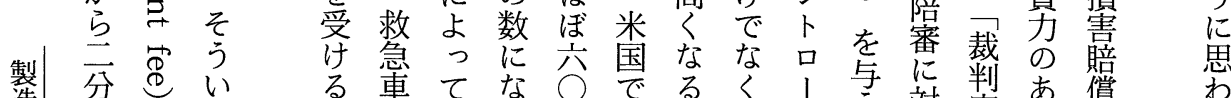

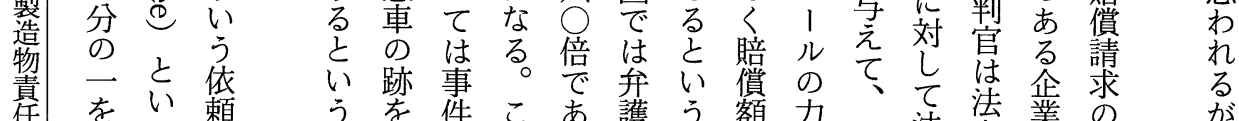

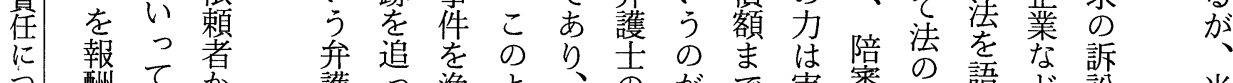

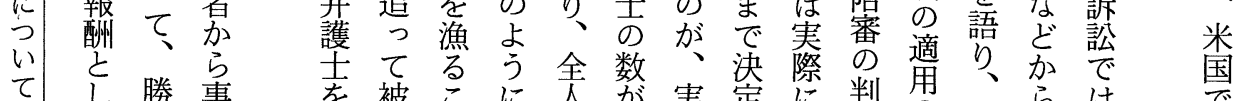

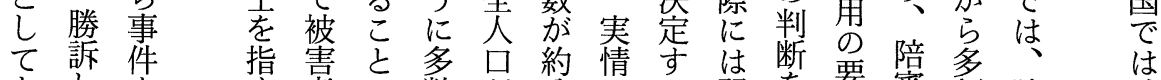

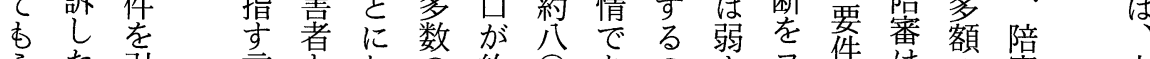

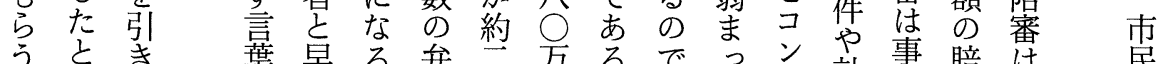

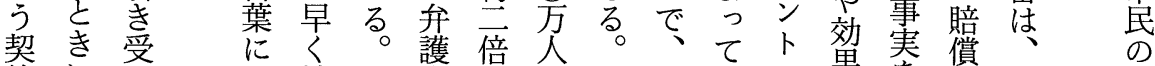

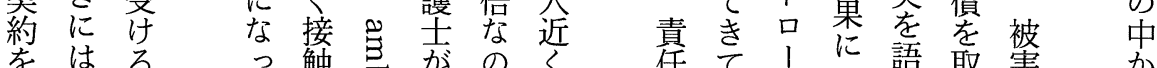

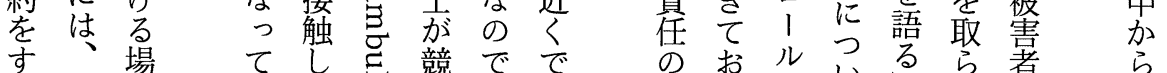

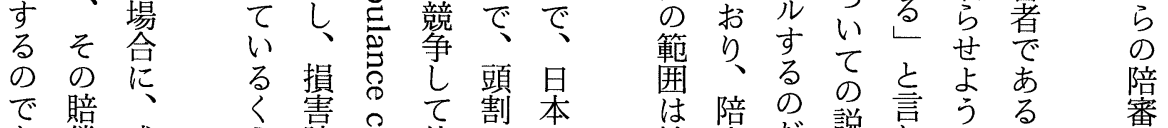

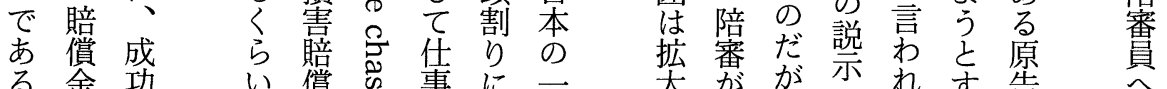

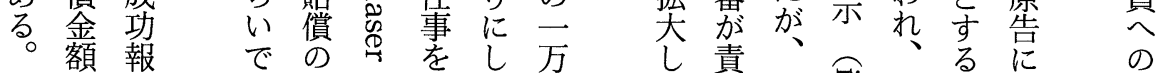

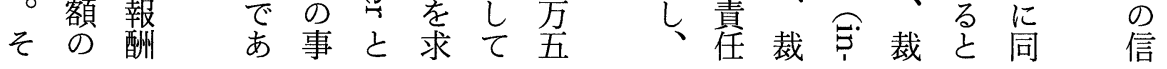

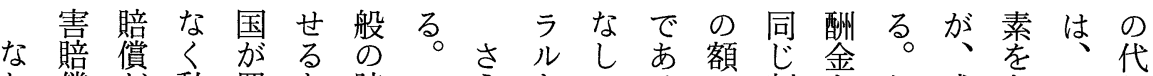

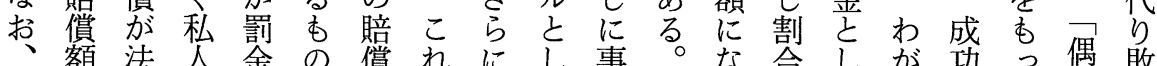
こ額法人金の償れににし事具る合し㤎功っ然敗

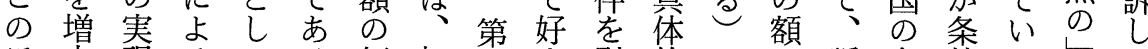
ほ大現るて る何驾言ま引的の气訴弁件る。た かさの法徵。倍害にしきに報つ訟護で。とと

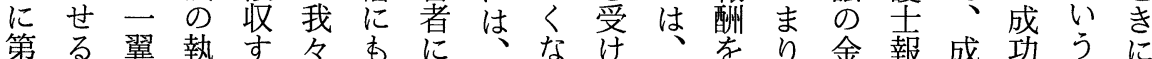
四大基行へ功害懲いるそ前額酬功報意は

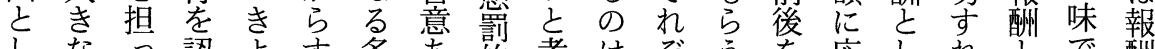
しな認よ方多市的考はぞう応しれてで酬

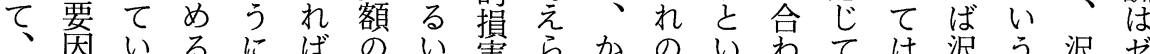

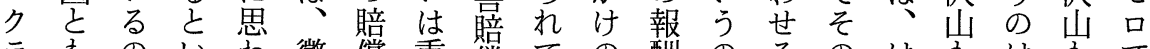

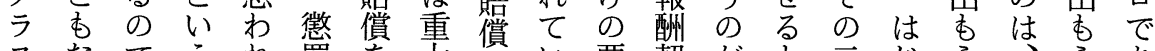

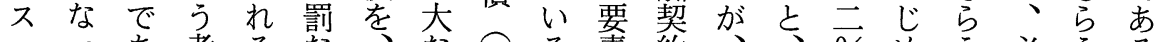

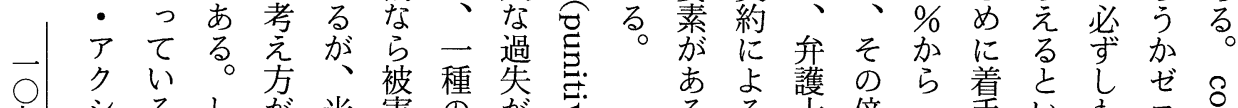

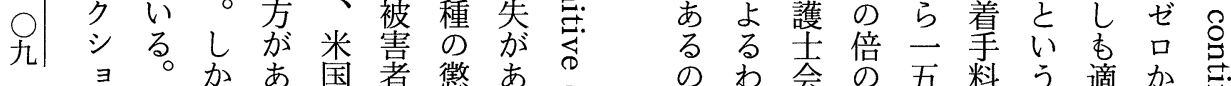

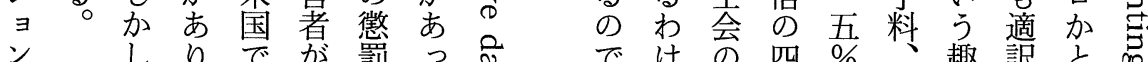

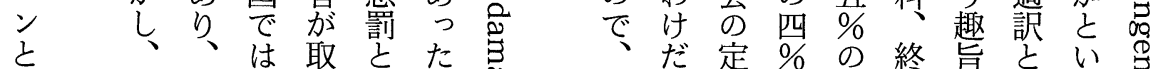

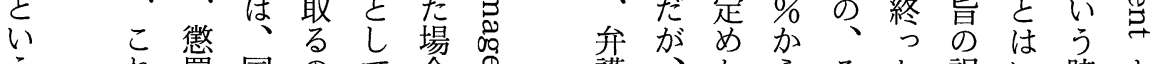

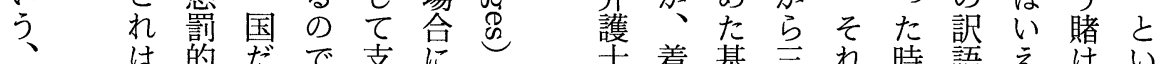

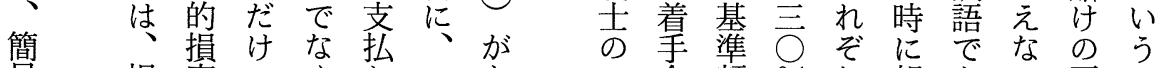
易損害でくわ—市金額\%禹報あい要の 
いれ業米こ格償み 立され害功者め因な

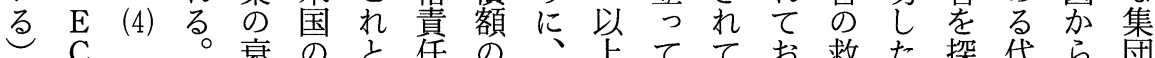

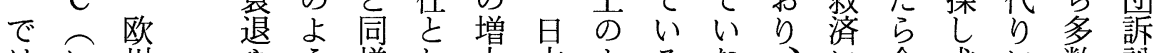

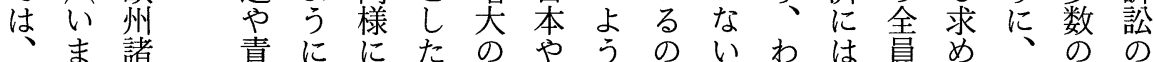
加は国任、無判原 $\mathrm{E}$ にで。が有に貝、被方

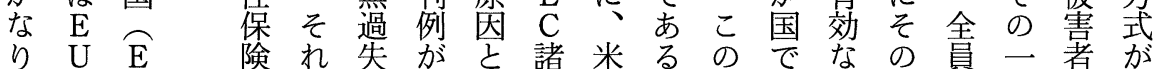

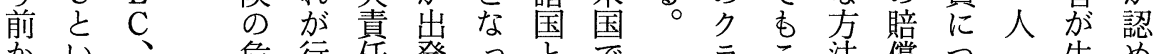

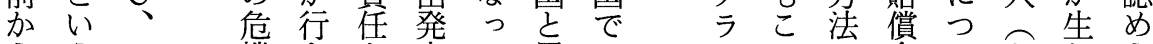
らう $\mathrm{E}$ 機き之点て 異

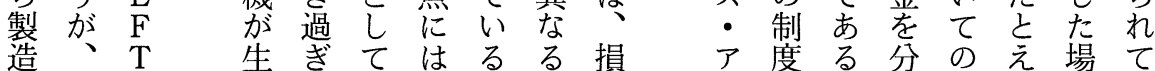
物こ $\mathrm{A}$ じて の な 責ごの た 損尔つ製色賠 の 検指法 る 償任 る 責 る 求

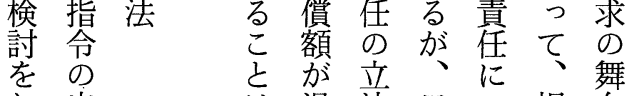

乙 出

き当 いた 市本い害を だの時 あ な る $\mathrm{E}$ は償 る

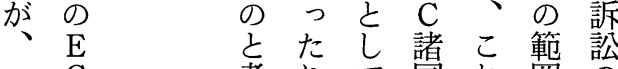

一 C 考り て 国れ苚訟

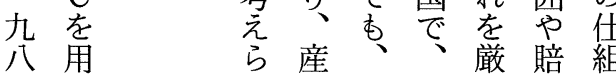

シ採し告償弁にる 苗

シ 用 が る 請 護 各 こ

が主、と訴

損されれう在袋別る 号

害れ賠た 伴の

償り管でし 主にれ

のた額し 䌘少てなっ 損は

拡が委 額 そて賠 同

に実摘数に被を成害求原

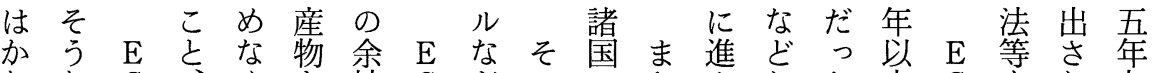

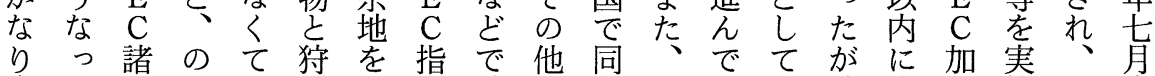
事て国三毛猟認令、のの様 $\mathrm{E}$ い、立盟施 $\mathrm{E}$ 末 情はで点よ物めに製地の $\mathrm{C}$ るまそ法二主 C に

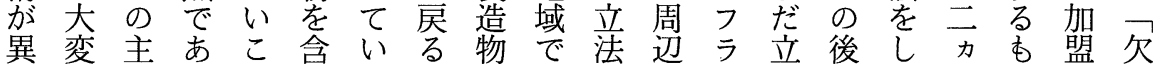

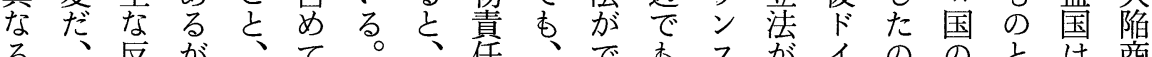

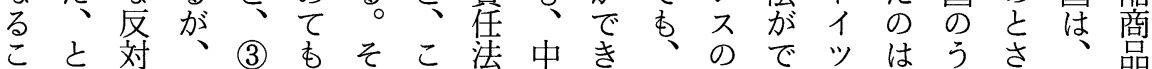

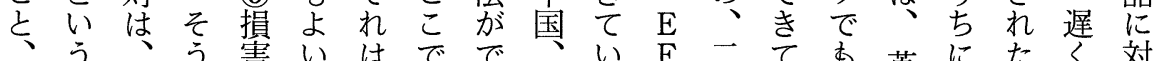

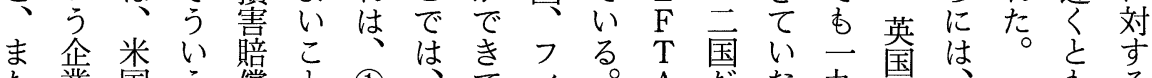
た業国 う償 こ

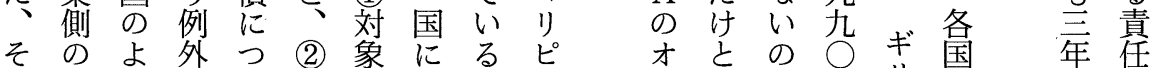
う反 う を

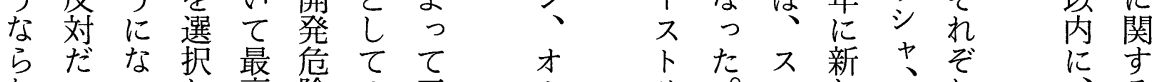

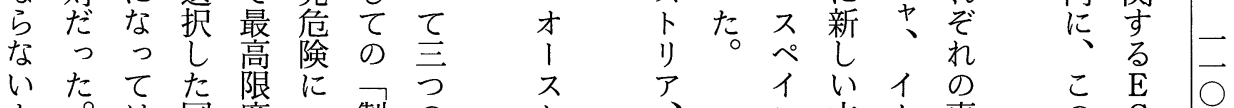

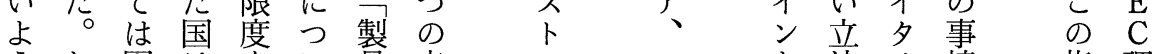
に年条は学い点点

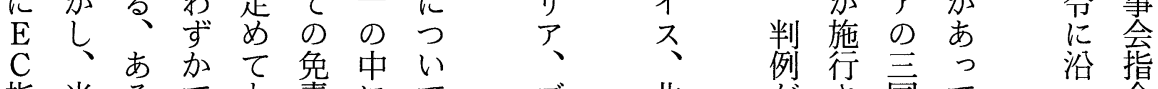

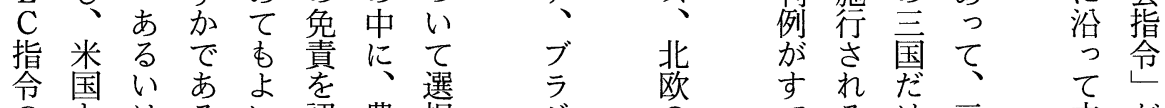

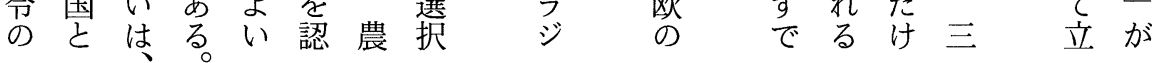




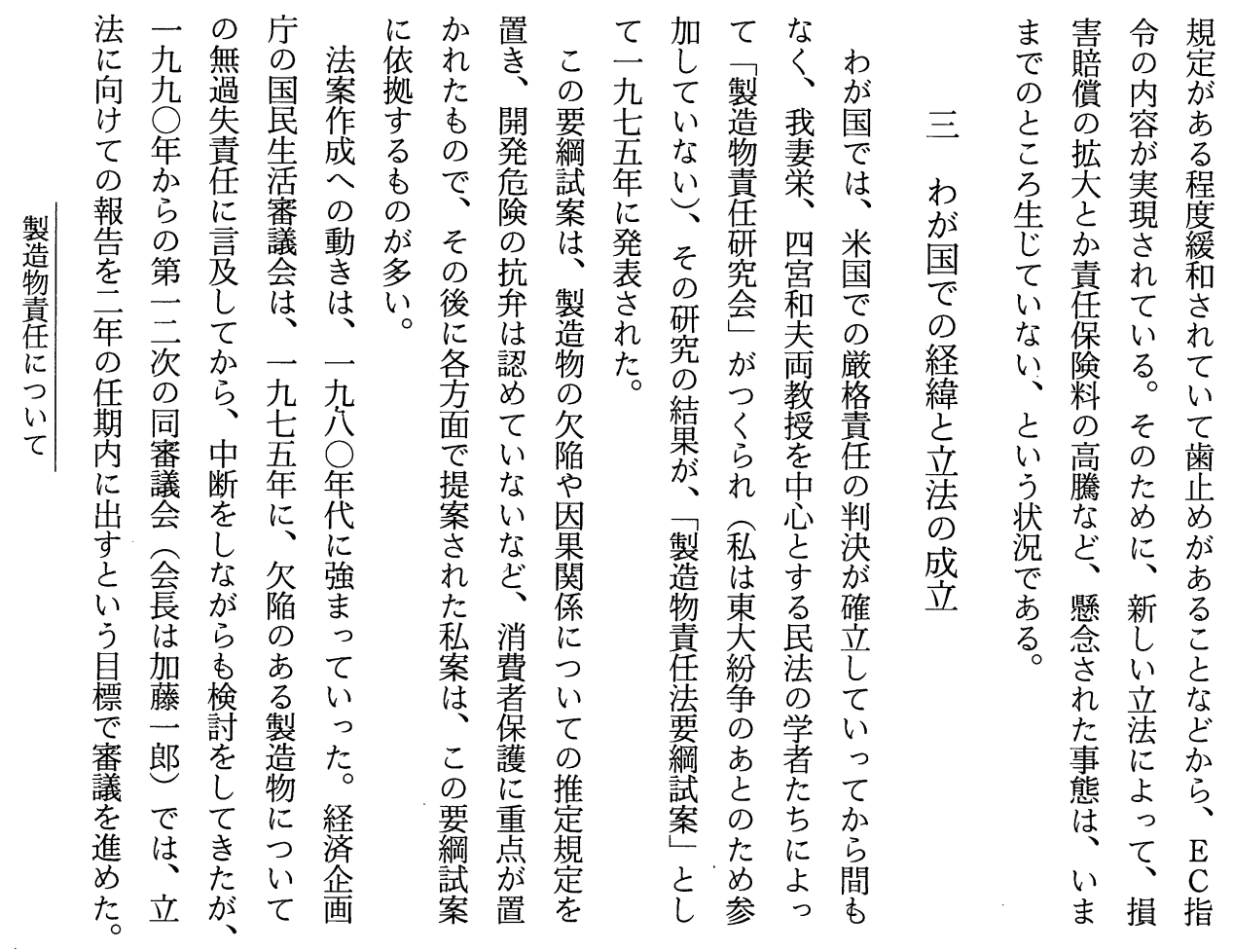

り四報義委法制ま報害防報前姇会輸 み年 前月そこ告行長審た告㱑告㤎な研通っばか

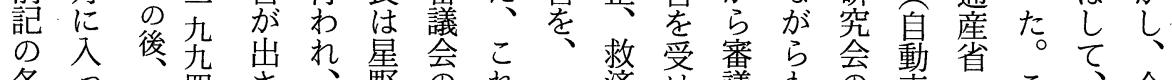

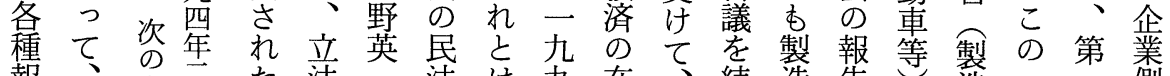

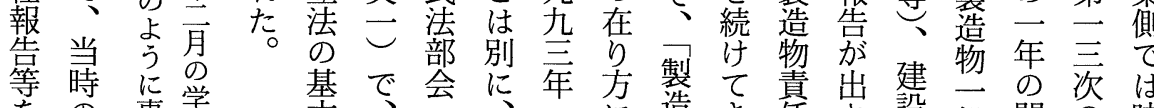

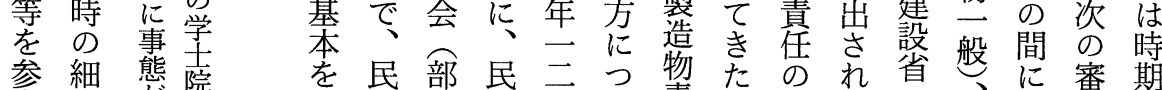

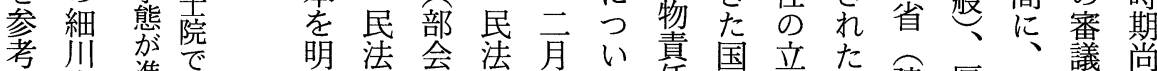

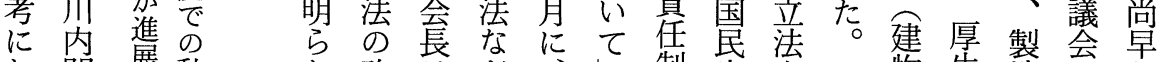

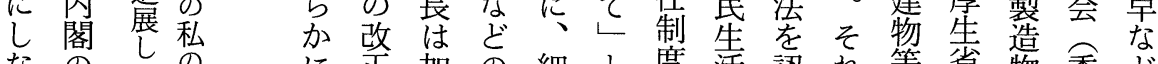
なの郝企加の細と度活認れ等省物委よ゙

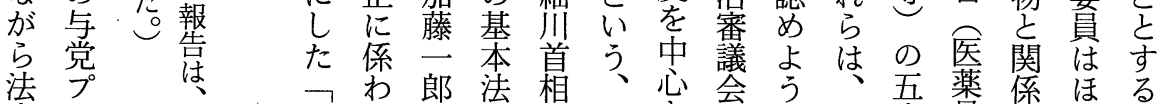

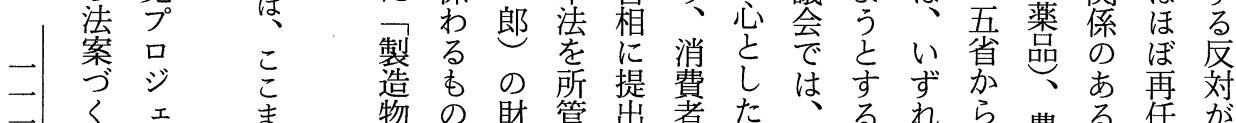
くェ 物の財管出者たはる れら農る任㤎

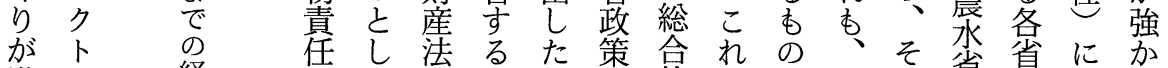

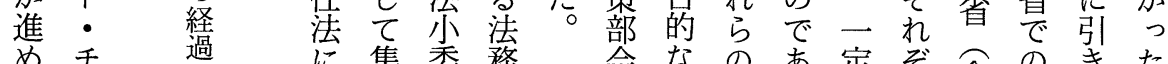

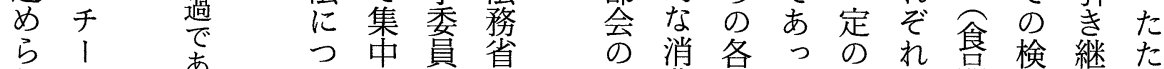

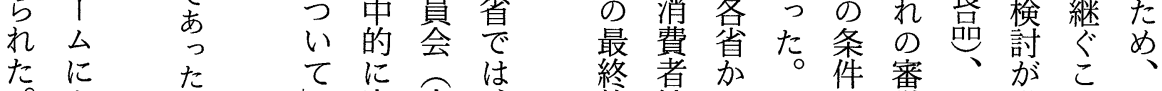

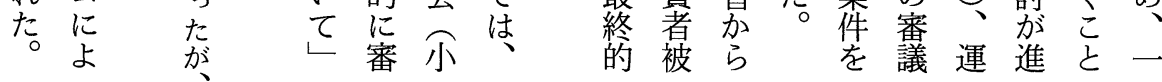


に嘸异他用諸が業業設八

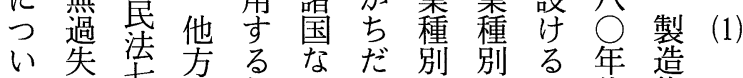

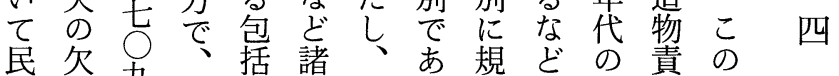

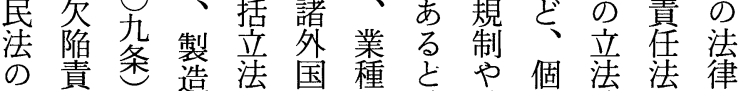

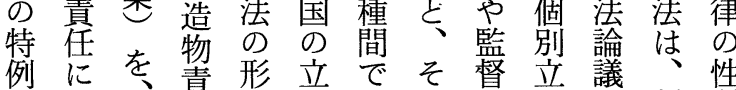

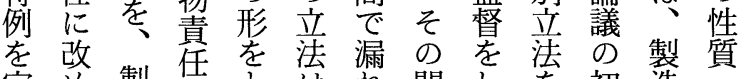

定め製法气机間し丢初造

めた造はっ法っるにて貝期物

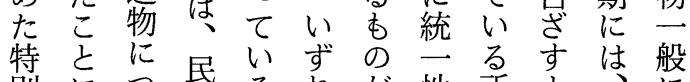

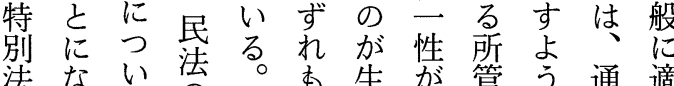

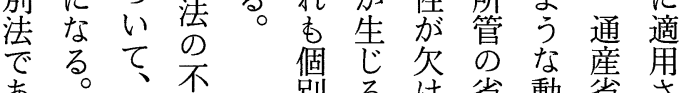

あする法立拉不省憅省ざ

なの行立之均に热製る

わ尔為告衡はあ品包

ち、陷法な方都っの括

そ責過製る告含た種立

れ任失造年る個別染

は要責物そこい別にあ

製牦任 般でにう法究る

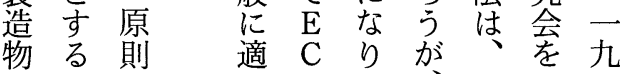

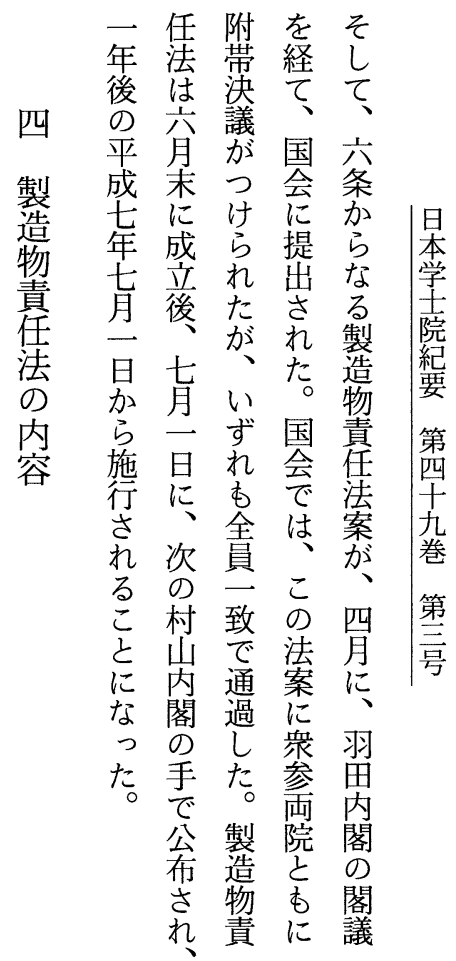

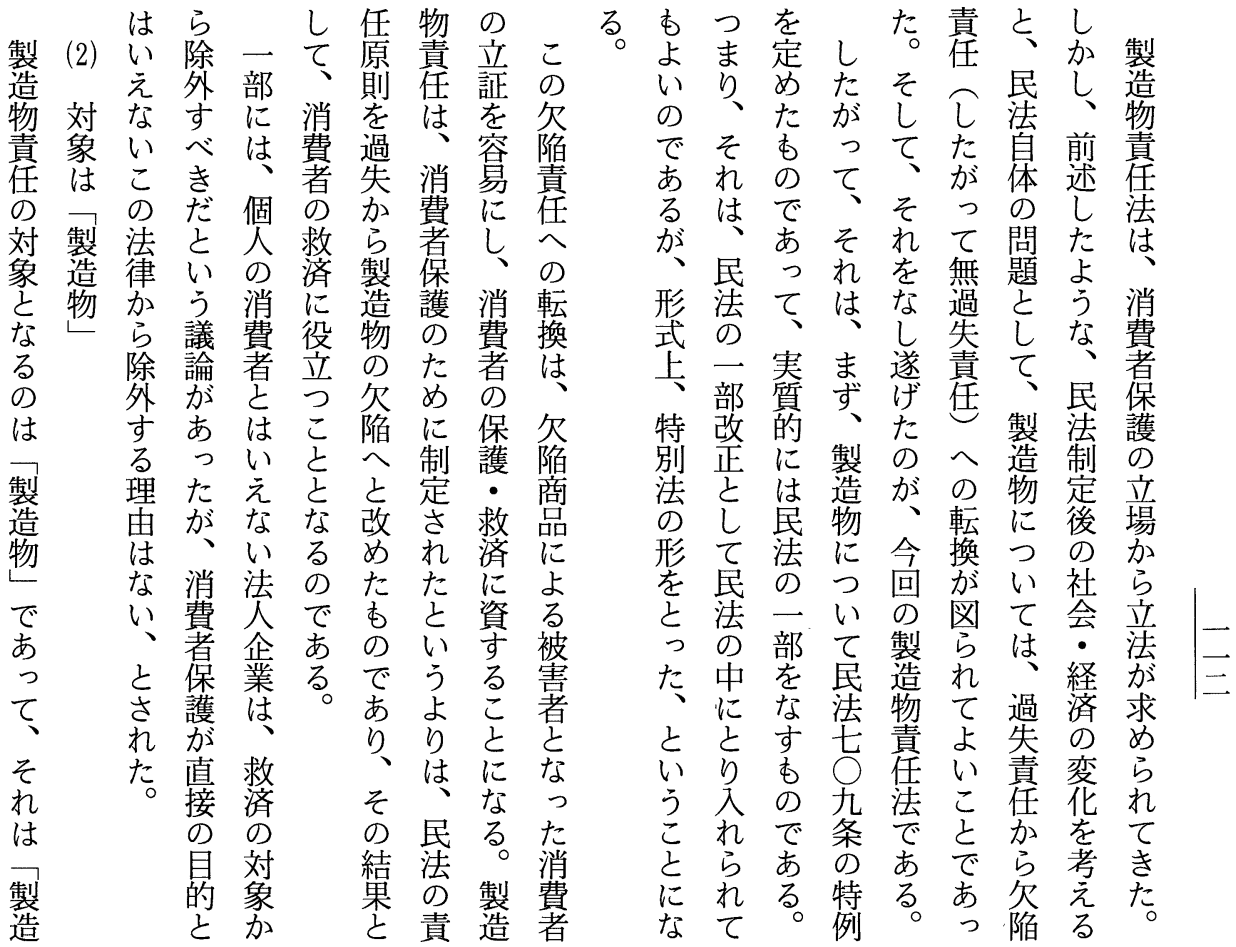



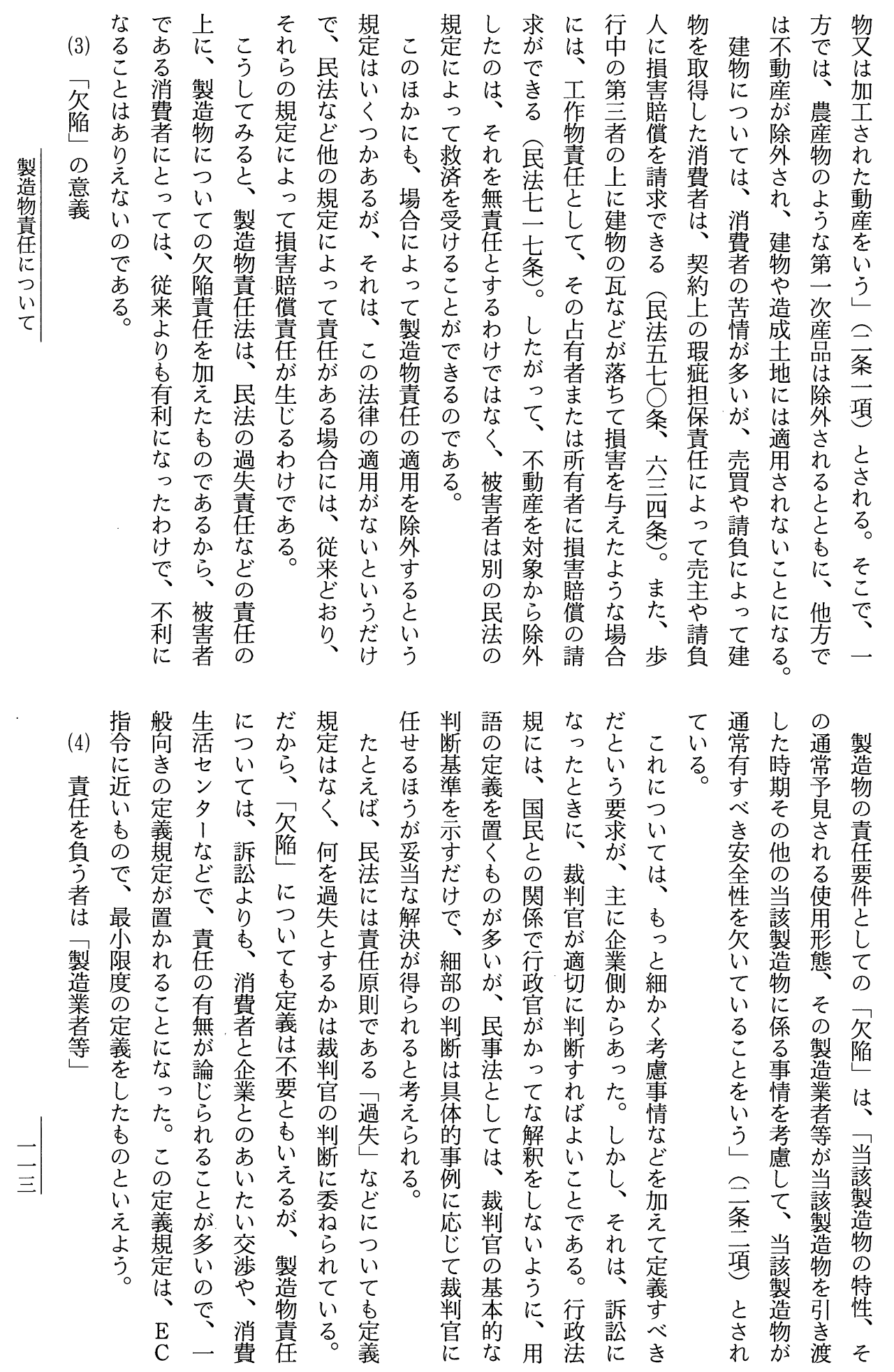


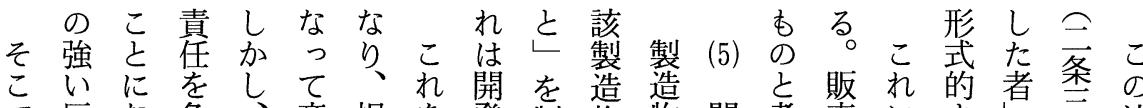

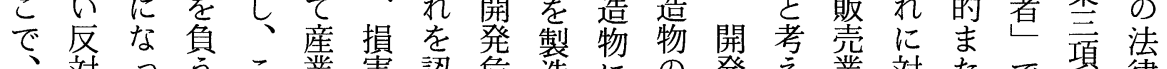

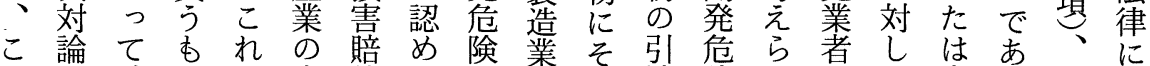
のが、のに衰償なの奢の渡険れは害るそょ

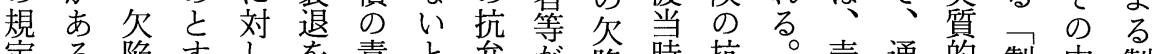

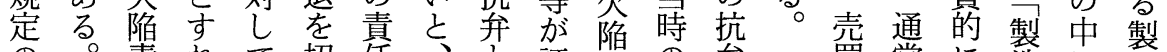
の責れて招往势証がの弁買常に造に造

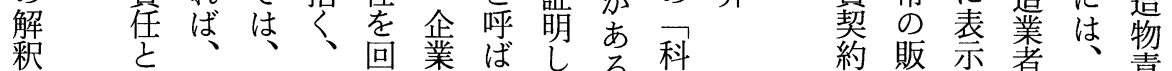

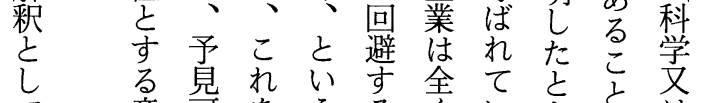

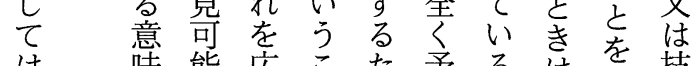
は味能広こな゙予る。証戏 こ 失基認㤎に新な 兔識関 ぞ机基楚業規か 責る等

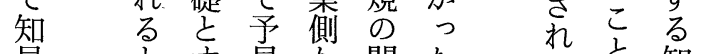

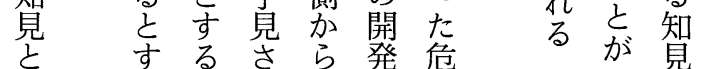

い尚過机はを険四でに

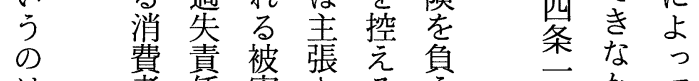

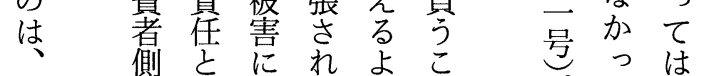

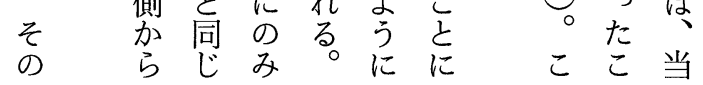
約賠を者責 よ業し同製牮

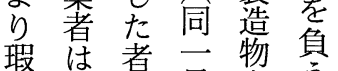
㩔は者号荡界 製同業 の 杂 造豆の采は

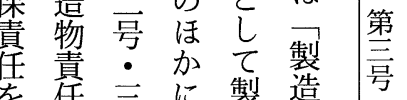

認な抗新医がる品和責件開いなお お最時

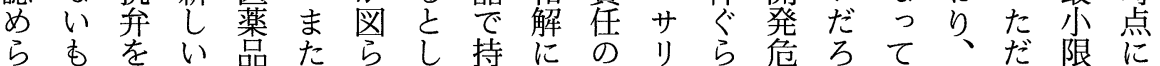

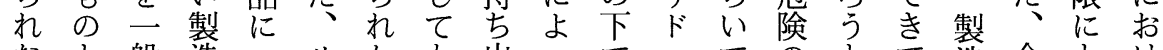
なと般造つサた市出つでマでのとて造今とけ いさに物いリり美さてはイあ抗思い物旦ぞる

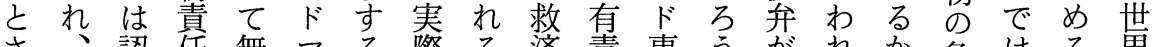
さ認任無、る際る済責事う恓れ加危はる 鱼 れ医め法過イこにこ斿占件。ある。ら険各最

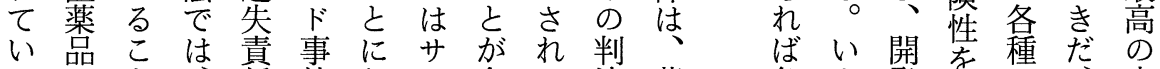
るに兄

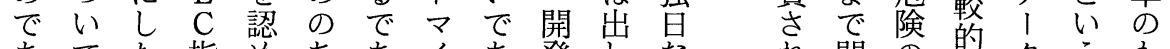
あてた指めちあイあ発しな的問の留多うあ

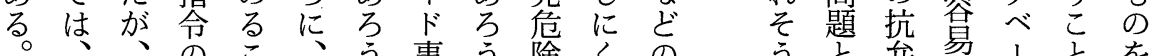

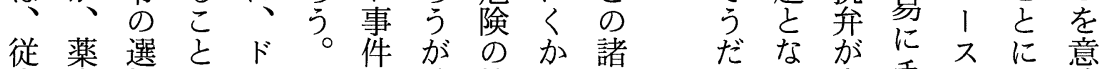
来事択にイ上小抗っ国方っ実チがな味 ぞ法規しッ同そ弁た茾たた際国っ夺

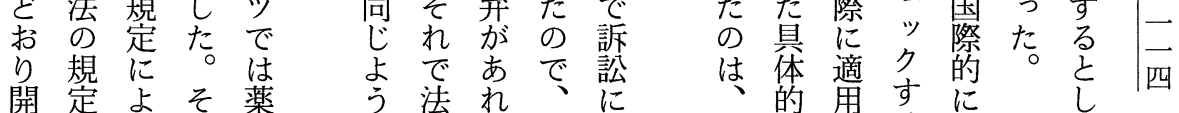

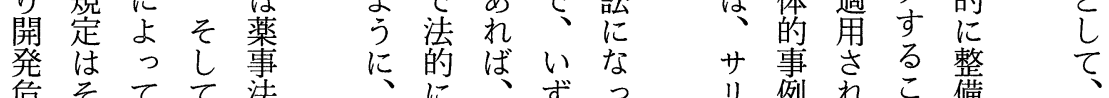

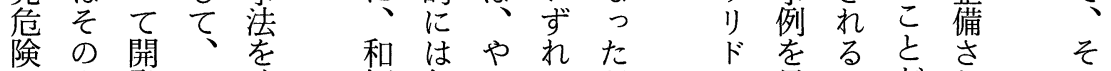

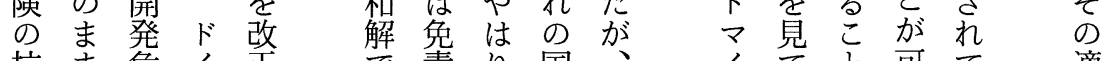
抗ま危イ正筫り国、イ元と可て 適

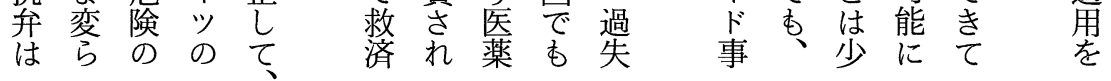




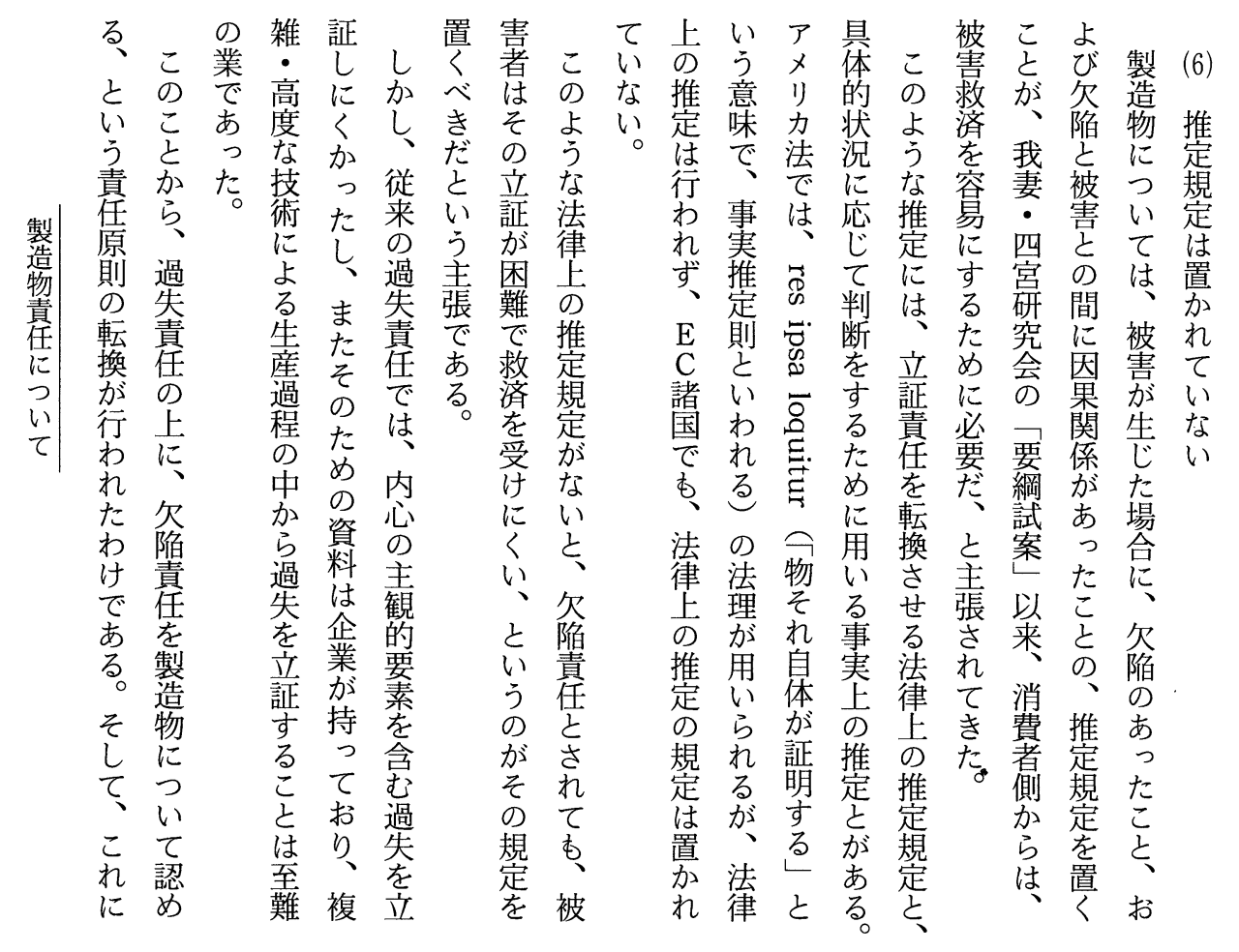

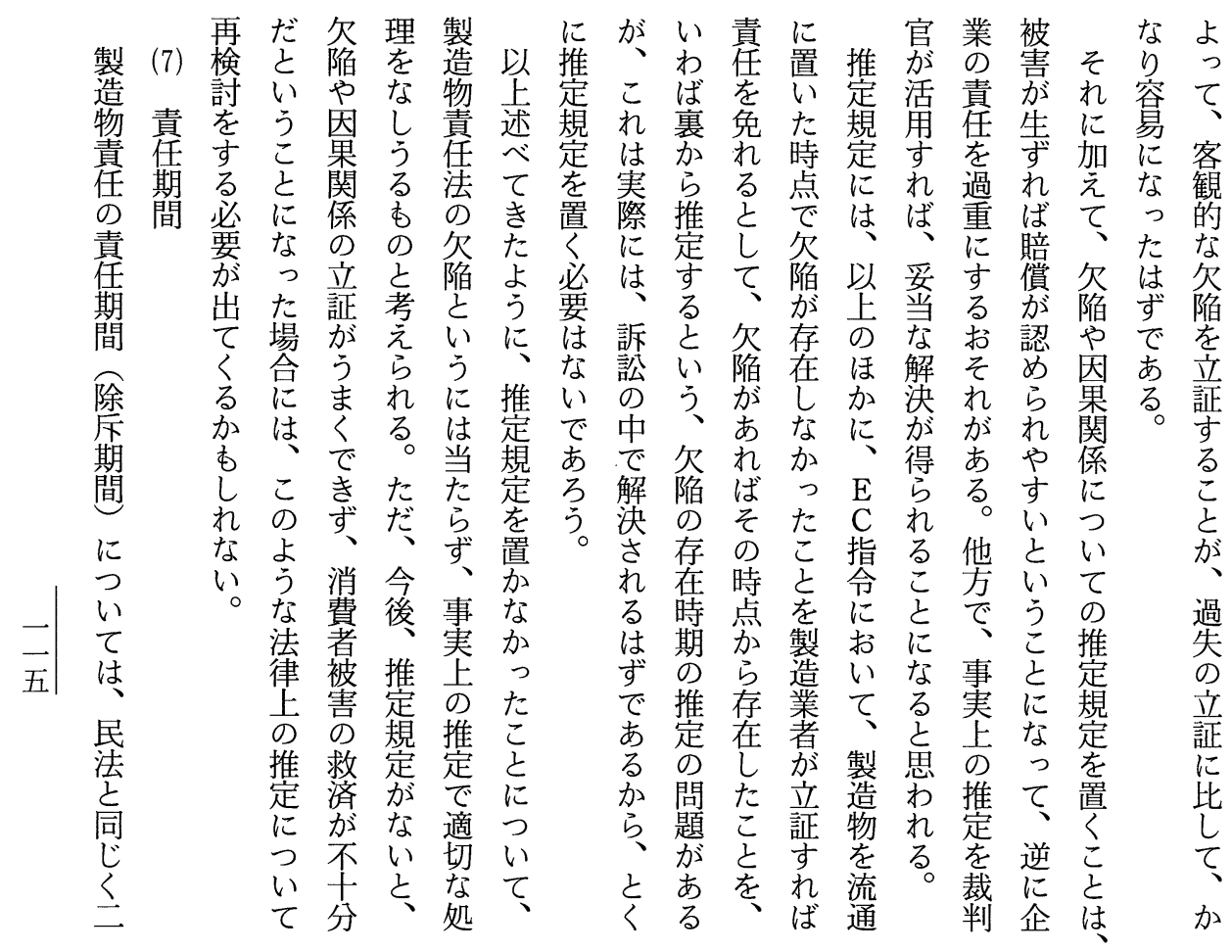




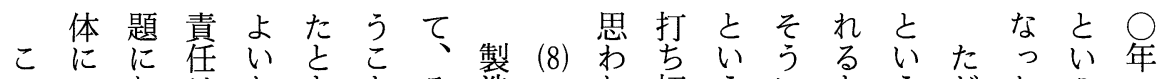

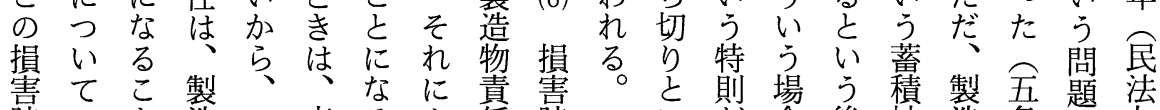

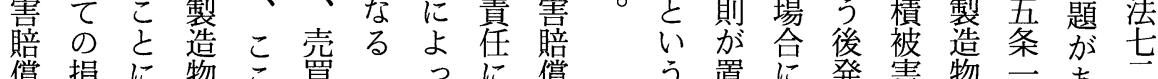

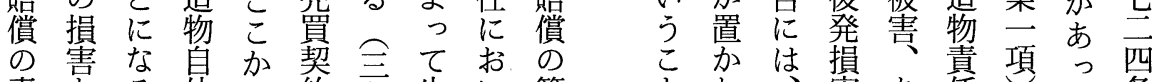

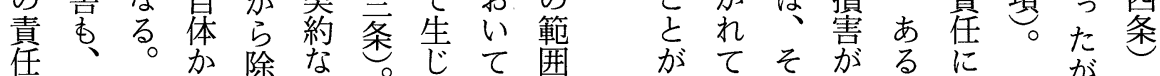
に併なら条どなたは

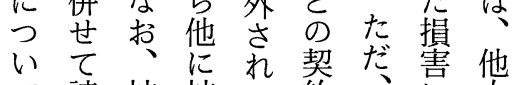

て請拡拡る約、に人 は求大乫大損つの

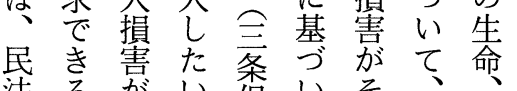
法るがい采いそ

規之瑟わ畫て損製造体 窝にたる。害造業希

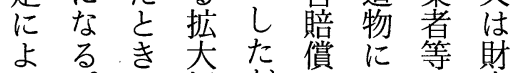
る。に損が少つ傍 ま は害つ請い賠の

の 製つて求て償侵 さ俈い製市み罢に

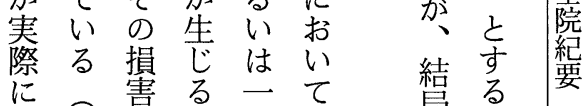
問吾害る 定 は 題条生 る 筫時ま期に蓄 時拎

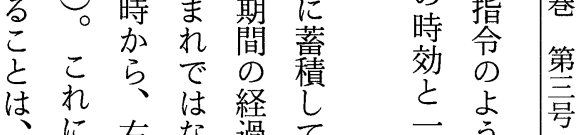
る 自問物ばじ負し

、に右な過て 可

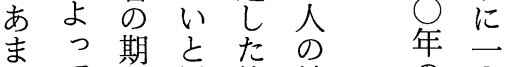
りて間思後健合? な、除年 い二計势症害质期省 の年导が品筧る

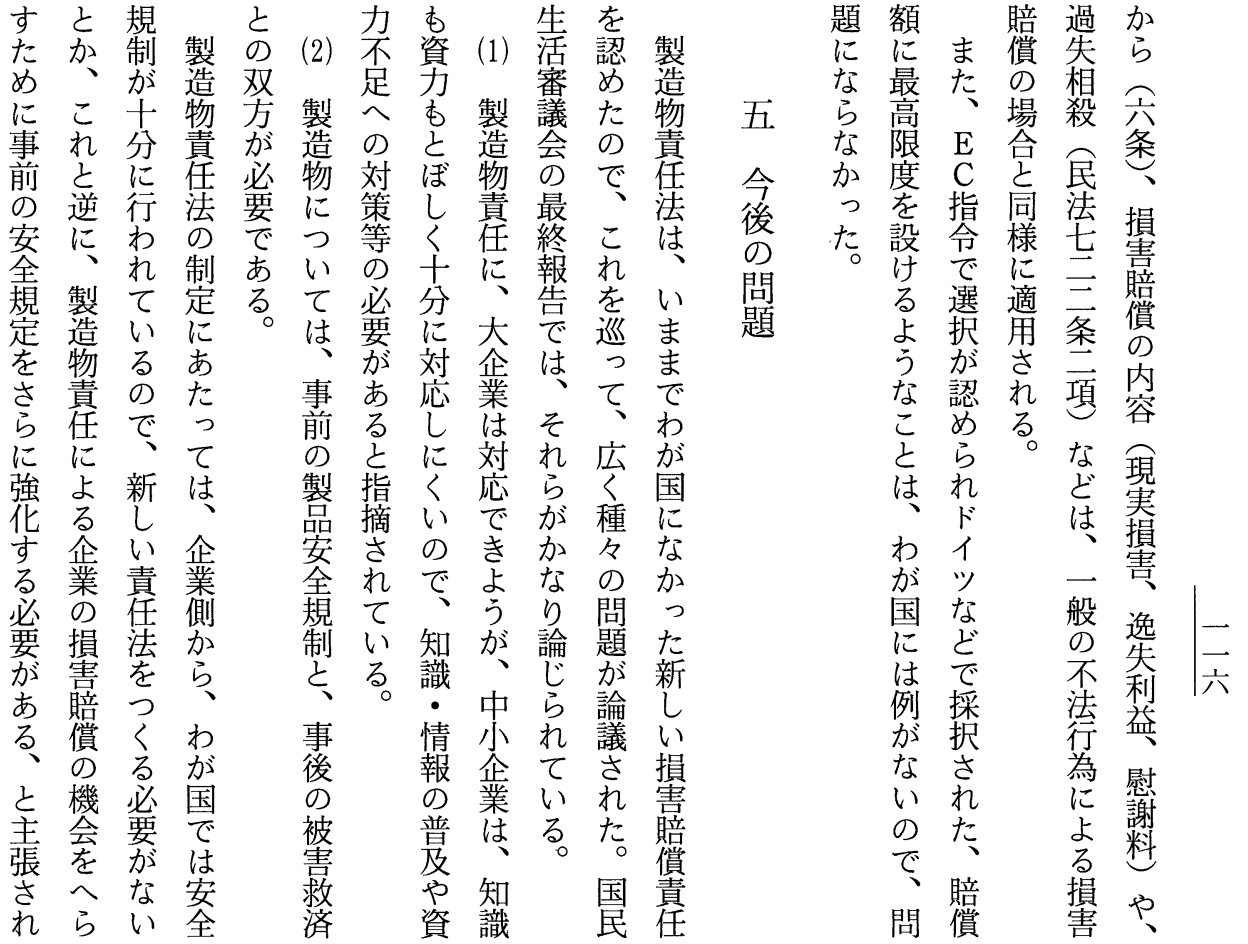




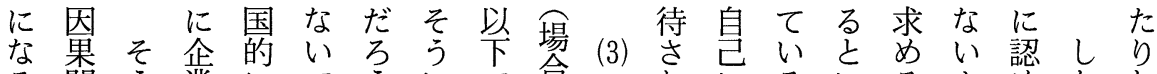

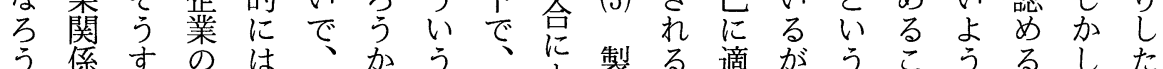

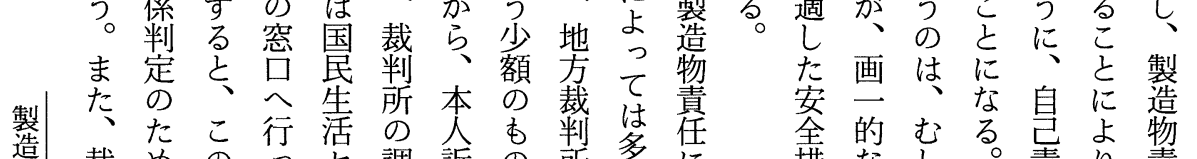

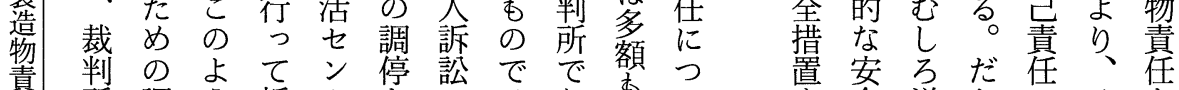

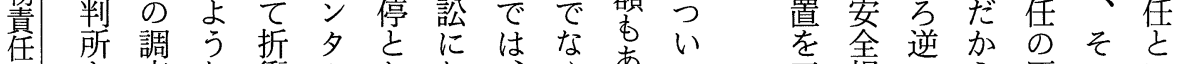

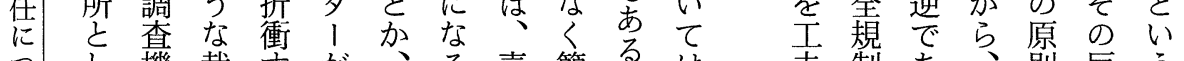

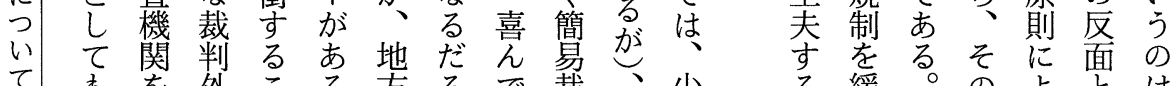

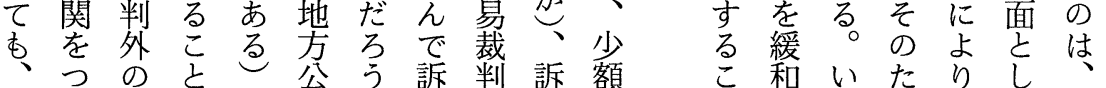

簡く紛にな共し訟所訟

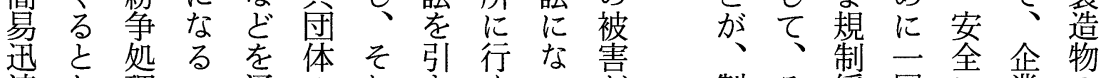

速か理で通のれきく㤎製そ緩層に業の

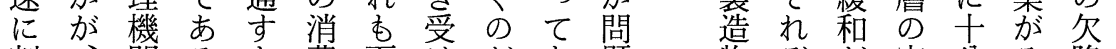

判、関ろと費面けが市題物ぞが安分そ樎

断政夺う吕告倒るふ心に責れ大全にうに

の府充。、活な弁つ訴な任のき規配いょ

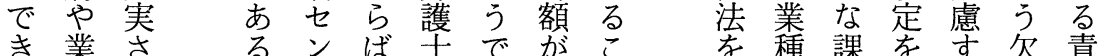

る界せ い多訴はあ杂通や題国る陥任

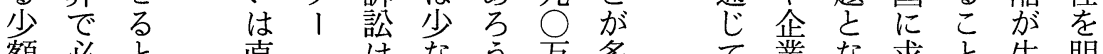

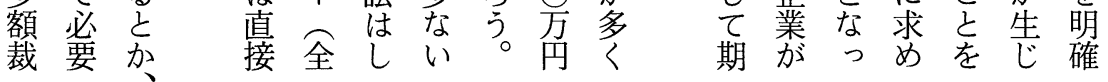

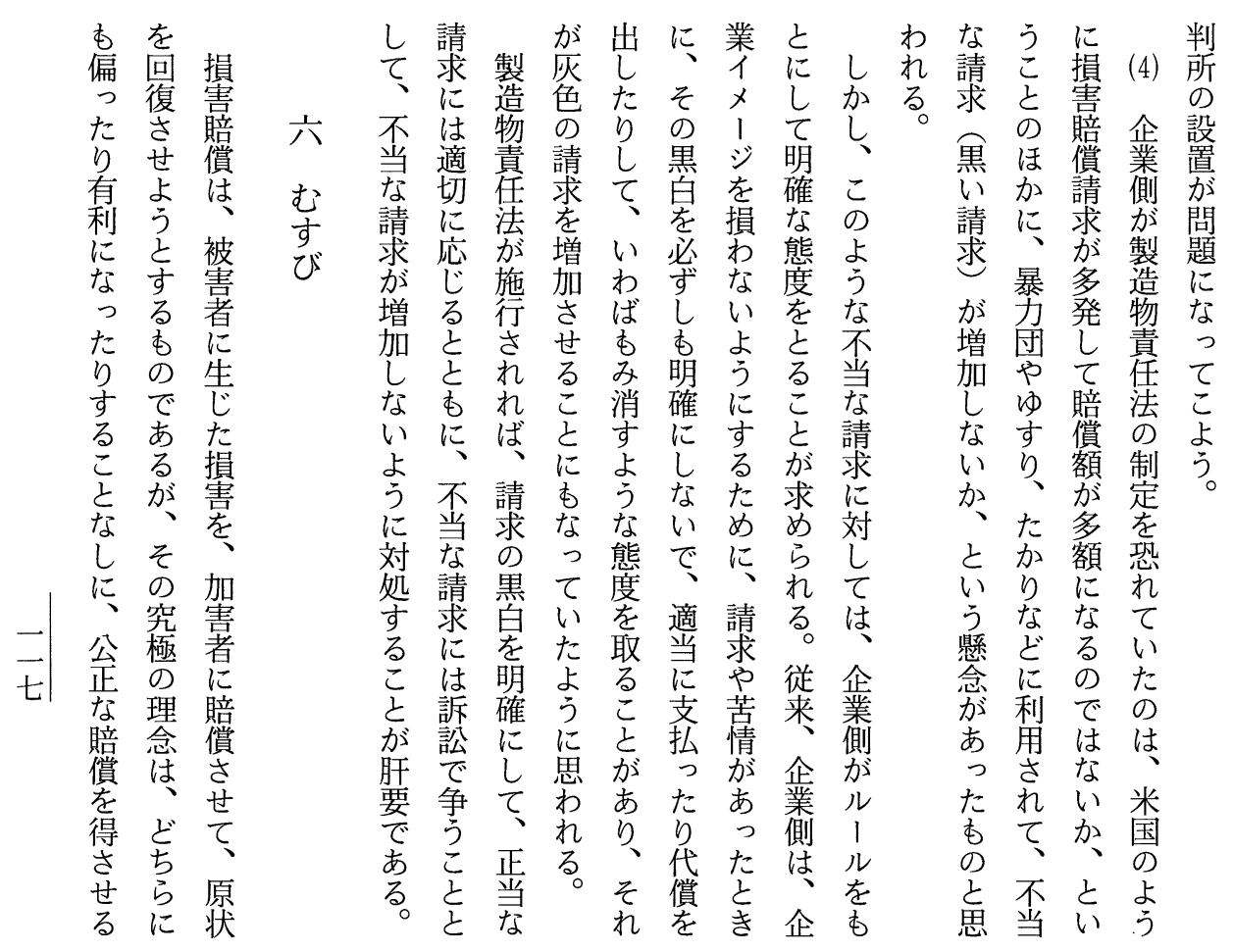




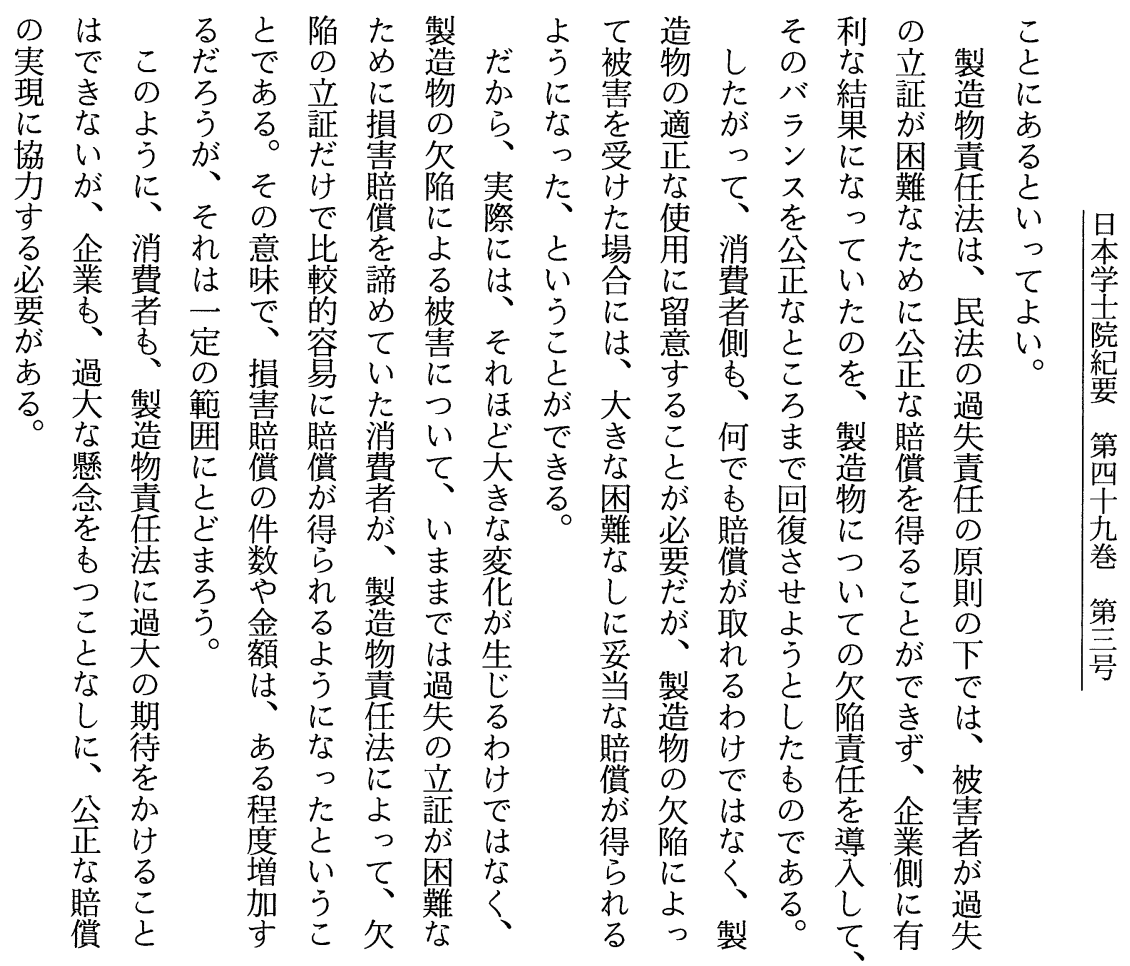


Its most discussed issue was so-called risk of development. The Law exempts liability when the manufacturer proves that the state of knowledge at that time was not such as to enable the existence of the defect in the product to be discovered. It adopted the EC type exemption in order not to hinder development of new products.

The other point was the presumption clause of defect and causation. The Law did not adopt it similar to the EC Directive. The court is expected to apply de facto presumption (res ipsa loquitur in Anglo-American law) in necessary cases.

The effect of the Law is not realized before its enforcement. However, I expect that the injured consumer will be easier to prove defect of product than negligence of the manufacturer and to recover damages. The Law will protect and improve the interest of consumer.

On the other hand, in Japan I do not mind the difficulties of product liability and the crisis of liability insurance in the United States, because the backgrounds of the tort law process are quite different between both countries.

In Japan, we do not have jury system, contingent fee practice, punitive damages and class action, which promoted enlargement of the product liability and higher damages in the United States. 


\section{On the Product Liability}

Ichiro KATO, M. J. A.

1. The Product Liability Law of Japan was enacted.

In Japan, the legislation of the Product Liability has been long discussed, since Greenman v. Yuba Power Products, Inc. in California had first established the strict liability of defective products in 1963 in the United States.

The first draft proposal of the Product Liability Law was published by a study group guided by Professors Sakae Wagatsuma and Kazuo Shinomiya in 1975. Recently after the EC had issued the Council Directive on the Liability of Defective Products in 1985 and European countries followed it thereafter, several draft proposals were published in Japan by academic and citizen groups as well as political parties. They almost followed the first draft proposal by Wagatsuma and Shinomiya.

In the Government, the Social Policy Council dealing with people's daily life under the Economic Planning Agency started deliberation of the product liability in 1990 aiming at its legislation.

The consumer groups and the academic world pushed such legislation. On the other side, industries, economic world and MITI were originally against such legislation, but gradually changed their posture. They feared of American experiences of the product liability, but tolerated EC type legislation. The MITI and other ministries, which have jurisdiction over industries in general and especially over pharmaceutical, food or so, together supported EC type legislation.

The Social Policy Council published its final report at the end of 1993, which recommended such legislation summarizing deliberation so far.

On the other hand, the Legislative Council under the Ministry of Justice joined them from the viewpoint to modify the negligence principle of Article 709 of the Civil Code towards no-fault (strict) liability as for defective products.

Following above deliberations in ministries, the Government proposed the new Law of Product Liability to the Diet in April 1994.

After approval of the Diet, the Product Liability Law was enacted on July 1, 1994 and will be enforced after one year.

2. The Feature of the Product Liability Law

The Law is composed of only 6 articles. It prescribes the principle of no-fault liability of defective products. The manufacturer shall be liable for damages caused by defective products. 